\title{
IKHTIAR PRODI PERBANDINGAN MAHDZAB FAKULTAS SYARIAH DAN HUKUM UNIVERSITAS ISLAM NEGERI SUNAN AMPEL MENINGKATKAN KOMPETENSI PENDIDIK MELALUI LESSON STUDY
}

\author{
Moch. Zainul Arifin \\ UIN Sunan Ampel Surabaya \\ zainularifin231@gmail.com
}

\begin{abstract}
ABSTRAK
Kajian ini merupakan ulasan ilmiah tentang peran lesson study dalam meningkatkan kompetensi dosen program studi perbandingan Madzab Fakultas Syariah dan Hukum UIN Sunan Ampel Surabaya yang dibiayai oleh penelitian tahun 2018 dalam cluster penelitian pepengembangan program studi. Kajian ini difokuskan pada pelaksanaan tahapan lesson study yang terdiri atas plan. do, dan see dengan tujuan untuk meningkatkan kompetensi Pendidik. Dengan demikian kajian ini dapat dikatagorikan sebagai action research. Metode yang digunakan adalah deskriptif kualitatif. Data dikumpulkan menggunakan instrument observasi, angket, dan pedoman wawancara. Data dianalisis menggunakan analisis grounded theory. Hasil kajian menunjukkan bahwa peran lesson study pada dapat meningkatkan kompetensi dosen. Hal ini dapat dilihat dari indikator tenaga pendidik berhasil menyusun silabi mata kuliah kajian teks Arab, yang sebelumnya silabi perkuliahan belum ada, pada pelaksanaan lesson study, silabus mata kuliah tersebut telah mampu disusun.
\end{abstract}

Kata kunci: Kompetensi Dosen, Lesson Study

\section{ABSTRACT}

This study is a scientific review of the role of lesson study in improving the competence of lecturers in the comparative study program of the Faculty of Sharia and Law at Sunan Ampel Surabaya UIN which was funded by a 2018 study in a cluster of research development programs. This study focused on the implementation of the lesson study phase which consists of a plan, do, and see with the aim of increasing the competence of Educators. Thus this study can be categorized as action research. The method used is descriptive qualitative. Data collected using observation instruments, questionnaires, and interview guidelines. Data were analyzed using grounded theory analysis. The results of the study indicate that the role of lesson study can improve the competence of lecturers. This can be seen from the indicators that the educators managed to compile a silabi on the subject of Arabic text study, which previously did not yet exist in the lecture silabi, in the implementation of lesson study, the syllabus of the course had been able to be compiled.

Keywords: Lecturer Competence, Lesson Study

\section{PENDAHULUAN}

Universitas Islam Negeri (UIN)

Sunan Ampel Surabaya yang merupakan institusi pendidikan Islam, telah mencangkan strategi utama dalam mencapai visi misinya yaitu diantaranya dengan melakukan peningkatan kapasistas SDM (http://www.uinsby.ac.id/id/187/ren

cana-strategi.html)

Peningkatan kapasitas yang dimaksud, sebagaimana dijelaskan oleh A'la yaitu semua kegiatan dan program yang diarahkan untuk memberdayakan SDM UIN Sunan Ampel Surabaya, yang terdiri atas 
tenaga pendidik dan kependidikan, baik di bidang kompetensi pedagogik, profesional, manajerial, pelayanan dan kompetensi bidang riset, serta kualifikasi kepribadian muslim dan sosial. Melalui agenda pertama ini diharapkan UIN Sunan Ampel Surabaya dapat meningkatkan kepuasan stakeholders pada sektor mutu pendidikan dan pengajaran seiring dengan meningkatnya kualitas dan kuantitas tenaga pendidik dan tenaga kependidikan.

Lebih lanjut, tolak ukur dari peningkatan kapasitas tersebut juga sudah ditetapkan. Adapun Indikatorindikator pada peningkatan kapasitas ini meliputi:

1. Kompetensi Pedagogik;

perencanaan, proses pembelajaran dan evaluasi.

2. Kompetensi Profesional; penguasaan bidang keahlian, penguasaan ICT, penguasaan bahasa asing, komunikasi, teamwork, independensi, pelaporan BKD secara mandiri.

3. Kompetensi Manajerial Pajabat eselon dan non-eselon; mampu merencanakan, melaksanakan dan mengevaluasi tugas sesuai tupoksi masing-masing.

4. Kompetensi Pelayanan; mampu merencanakan, melaksanakan dan mengevaluasi tugas sesuai standar pelayanan minimum masingmasing.

5. Kompetensi Riset; kemampuan metodologi, responsif terhadap isu-isu strategis, integritas keilmuan, komunikasi dan publikasi hasil riset

6. Kompetensi Pengabdian; kemampuan memenuhi kewajiban pengabdian masyarakat berbasis penelitian.

7. Kualifikasi Kepribadian Muslim dan Sosial; memiliki integritas terhadap nilai-nilai Islam transformatif serta menjunjung tinggi nilai-nilai humanis.

Peningkatan kapasitas SDM dengan indikatornya kompetensi pedagogik tenaga pendidik inilah yang kemudian coba ditindaklanjuti oleh Prodi Perbandingan Mahdzab Fakultas syariah dan Hukum UIN Sunan Ampel Surabaya. Peningkatan kapasitas SDM yang dilakukan oleh Podi Perbandingan Mahdzab selama ini yang telah dilakukan yaitu mengirim dosen-dosen di prodi Perbandingan Mahdzab untuk melakukan studi banding, seminar, pelatihan.

Secara garis besar, peningkatan kapasitas SDM yang dilakukan oleh prodi Perbandingan Mahdzab Fakultas Syariah dan Hukum UIN Sunan Ampel Surabaya lebih fokus pada kemampuan tenaga pendidik terkait dengan keilmuan. Sedangkan terkait dengan perencanaan, proses pembelajaran dan evaluasi yang merupakan indikator dari peningkatan kapasitas SDM terkait dengan kompetensi pedagogik terkesan belum tersentuh. 
Sisi yang lain, dalam dunia pendidikan ada salah satu cara untuk melakukan pembinaan profesi pendidik yang dikenal dengan Lesson Study, Lesson study didefinisikan sebagai suatu model pembinaan profesi pendidik melalui pengkajian pembelajaran secara kolaboratif dan berkelanjutan, berlandaskan prinsipprinsip kesejawatan untuk membangun masyarakat belajar (Susilo, 2013:1).

Lesson Study (LS) menurut Stigler \& Hiebert dalam Padlurrahman (2013:84) pertama kali dilakukan di Jepang, kegiatan ini dinilai sebagai salah satu rahasia keberhasilan Jepang dalam meningkatkan kualitas pendidikannya. Lebih dari itu, melalui LS dapat ditingkatkan keempat kompetensi pendidik yaitu kompetensi kepribadian karena akan semakin meningkat motivasi pelakunya untuk berkembang, kompetensi sosial karena akan semakin kuat hubungan kesejawatan, kompetensi profesional karena akan semakin meningkat penguasaan materi ajar, dan kompetensi pedagogik karena akan semakin meningkat kemampuan merencanakan dan melaksanakan pembelajaran, mengamati kegiatan belajar, mewujudkan pembelajaran yang menyiapkan pebelajar untuk kehidupan masa depan, dan pada gilirannya memungkinkan perbaikan kualitas pembelajaran secara terus menerus (Susilo, 2013:1).
Berangkat dari dua sisi, yaitu sisi terkait dengan peningkatan kapasitas yang telah dilakukan oleh prodi Perbandingan Mahdzab Fakultas Syariah dan Hukum UIN Sunan Ampel Surabaya yang terkesan belum menyentuh pengembangan paedagogik yang merupakan indikator dari salah satu langkah yang ditetapkan oleh universitas dalam mencapai visi misinya. Sisi yang satunya yaitu tentang Lesson Study (LS) yang memungkinkan untuk menjadi alternatif dalam melakukan pembinaan tenaga pendidik. Maka dengan ini, penulis tertarik untuk melakukan penelitian di prodi Perbandingan Mahdzab dengan judul Implementasi Lesson Study Di Prodi Perbandingan Mahdzab Fakultas Syariah Dan Hukum Universitas Islam Negeri Sunan Ampel Sebagai Upaya Meningkatkan Kompetensi Pendidik yaang didanai oleh program penelitian tahun 2018. Sedangkan makalah, ini adalah pemparan hasil dari penelitian yang telah penulis lakukan.

Berdasarkan uraian tersebut, maka rumusan masalah pada penelitian ini yaitu

1. Bagaimana langkah-langkah implementasi Lesson Study (LS) di Prodi Perbandingan Mahdzab Fakultas Syariah dan Hukum UIN Sunan Ampel Surabaya?

2. Bagaimana hasil implementasi Lesson Study (LS) di Prodi Perbandingan Mahdzab Fakultas Syariah dan Hukum UIN Sunan 
Ampel Surabaya terhadap peningkatan kompetensi pendidik?

\section{Sejarah Lesson Study}

Lesson Study yang dari negara asalnya Jepang disebut dengan Jugyokenkyu. adalah suatu pendekatan peningkatan kualitas pembelajaran Amerika serikat Lesson Study mulai dipelajari di Amerika sejak dilaporkannya hasil Third International Mathematics and Science Study (TIMSS) pada tahun 1996. Dalam Laporan TIMSS itu mahasiswa Jepang, punya rangking tinggi dalam matematika dan diduga salah satu faktor pendukungnya adalah Jugyokenkyu tersebut (WangIverson dan Yoshida, 2005).

Selaras dengan Itu, perkembangan Lesson Study di Indonesia sebagaiamana dijelaskan oleh Susilo (2013) yaitu Lesson Study telah dilaksanakan di Indonesia sejak tahun 2006 melalui Program SISTTEMS (Strengthening In-Service Teacher Training of Mathematics and Science Education at Secondary Level) yang didukung Direktorat PMPTK, DIKTI, dan JICA. Lesson Study awalnya dilakukan terutama di tiga kota yaitu Sumedang, di dalam kolaborasi dengan Universitas Pendidikan Indonesia (UPI) Bandung, Bantul, kolaborasi dengan Universitas Negeri Yogyakarta (UNY), dan Pasuruan, kolaborasi dengan Universitas Negeri Malang (UM). Lebih lanjut Susilo menjelaskan bahwa menurut Ibrohim
(2010), saat ini lesson study telah diadopsi oleh tiga direktorat, yakni Direktorat Ketenagaan - DIKTI, Direktorat Pembinaan Diklat (Bindiklat) dan Direktorat Tenaga Pendidik (Tendik) - PMPTK. DIKTI melalui Ditnaga (2008-2010) melaksanakan suatu Program Perluasan Lesson Study untuk LPTK di Indonesia (direncanakan 2008-2015). Dalam program ini UM, UNY dan UPI ditunjuk sebagai universitas pendamping bagi LPTK lain. Mulai tahun 2011, Program Perluasan dan Penguatan Lesson Study untuk LPTK yang dalam bahasa Inggrisnya disebut LEDIPSTI (Lesson Study Dissemination Program for Strengthening Teacher Education in Indonesia) tidak lagi di bawah Ditnaga, tetapi dialihkan di bawah pembinaan Belmawa (Direktorat Pembelajaran dan Kemahamahasiswaan). Sementara PMPTK sedang mengembangkan Program BERMUTU (Better Education through Reformed Management and Universal Teacher Upgrading) bekerjasama dengan Bank Dunia dan Pemerintah Belanda (2008-2013) yang diterapkan di 75 Kota/Kabupaten dalam 16 Provinsi. Selain itu Program SISTTEMS yang telah berakhir pada bulan Oktober 2008, berikutnya telah dikembangkan menjadi program baru yang diberi nama Program PELITA (Program for Enhancing Quality of Junior Secondary Education) atau Program Peningkatan Kualitas 
Pendidikan SMP dan MTs. Program

yang dilaksanakan Tahun 2009-2012 memperluas daerah binaannya, yakni selain tiga kabupaten lama di Jawa juga meliputi Kota Padang, Kabupaten Minahasa Utara, Kabupaten Banjar Baru dan Provinsi Banten. Khusus Banten mengembangkan Program PSBM (Participatory School-Based Management).

\section{Pengertian Lesson Study} Lesson study sebagaimana dijelaskan oleh Anggara (2012;189) bahwa lesson study adalah sebuah model pembinaan profesi Dosen dalam meningkatkan kinerja Dosen yang dilakukan secara bersama-sama oleh sekelompok Dosen demi mewujudkan kinerja Dosen ke arah yang lebih baik lagi.

Berdasarkan

pengertian tersebut maka lesson study menurut hemat penulis tepat untuk dijadikan sebagai jalan Prodi Perbandingan Mahdzab Fakultas Syariah dan Hukum UIN Sunan Ampel Surabaya dalam rangka meningkatkan kompetensi pendidik.

\section{Pelaksanaan Lesson Study}

Lesson study merupakan model pembinaan profesi Dosen dalam pelaksanaannya terdiri dari beberapa tahap yang harus dilakukan. Mulyana (dalam Rusman dalam Anggara, 2012:190) menyebutkan bahwa ada 4 tahap dalam melaksanakan leson study, yakni:

\section{Tahap Perencanaan}

Dalam tahap ini Dosen yang tergabung dalam lesson study secara kolaboratif menyusun RPP yang berpusat kepada mahasiswa. Perencanaan be-rawal dari analisis terhadap kebutuhan dan permasalahan yang dihadapi dalam pembelajaran, seperti: kompetensi dasar, cara membelajarkan mahasiswa, menyiasati kekurangan fasilitas belajar, dan secara kolaboratif juga Dosen-Dosen mencari solusi dalam memecahkan permasalahan yang ditemukan tersebut. Dari hasil analisis DosenDosen tersebut diharapkan menjadi bahan pertim-bangan dalam penyusunan RPP untuk diterap-kan pada proses pembelajaran.

\section{Tahap Pelaksanaan}

Pada tahap ini ada dua kegiatan utama yakni kegiatan pelaksanaan pembelajaran yang dilaku-kan oleh salah seorang Dosen yang disepakati atau atas permintaan sendiri untuk mempraktikan RPP yang telah disusun bersama dan kegiatan observasi yang dilakukan oleh Dosen-Dosen lain yang bertindak sebagai observer atau pengamat

\section{Tahap Refleksi}

Tahap ini dilakukan dalam bentuk diskusi yang diikuti oleh seluruh peserta lesson study yang 


\begin{abstract}
dipandu oleh seorang
ketua.Diskusi dimu-lai dari

penyampaian kesan-kesan Dosen

yang telah mempraktikan

pembelajaran. Selanjutnya, semua

pengamat menyampaikan

tanggapan atau saran secara bijak

terhadap proses pembelajaran

yang telah dilaksanakan yang

didukung oleh bukti-bukti yang

diperoleh dari hasil pengama-tan,

tidak berdasarkan opininya

sendiri. Hal ini dilakukan sebgai upaya perbaikan proses pembelajaran kedepannya.
\end{abstract}

\section{Tahap Tindak Lanjut}

Tahap ini merupakan tahap terakhir dalam lesson study sebagai bentuk untuk menindaklanjuti hasil dari refleksi terhadap kegiatan les-son study.

\section{Prodi Perbandingan Mahdzab}

Prodi Perbandingan Mahdzab Fakultas Syariah dan Hukum UIN Sunan Ampel Surabaya sebagaimana yang ada dalam forlap dikti bahwa kode program studi ini yaitu 50202 dengan tanggal berdiri 11 Maret 2015 dan saat ini rasio dosen yaitu 1 dibanding 7,4. Adapun dosen yang ada dalam prodi ini sebagaimana yang tercantum dalam forlap dikti yaitu Akh, Mukarram, A. Mufti Khazin, A. Dzarrin Al Hamidy, Imroatul Azizah, Umi Chaidaroh, Agus Solikin, Siti Tatmainul Qulub, Sumarkan, M. Sulthon.

\section{Kompetensi Pendidik}

Peningkatan kapasitas yang dimaksud adalah semua kegiatan dan program yang diarahkan untuk memberdayakan SDM UIN Sunan Ampel Surabaya, yang terdiri atas tenaga pendidik dan kependidikan, baik di bidang kompetensi pedagogik, profesional, manajerial, pelayanan dan kompetensi bidang riset, serta kualifikasi kepribadian muslim dan sosial. Melalui agenda pertama ini diharapkan UIN Sunan Ampel Surabaya dapat meningkatkan kepuasan stakeholders pada sektor mutu pendidikan dan pengajaran seiring dengan meningkatnya kualitas dan kuantitas tenaga pendidik dan tenaga kependidikan. Indikatorindikator yang diamati:
1. Kompetensi Pedagogik; perencanaan, proses pembelajaran dan evaluasi.
2. Kompetensi Profesional; penguasaan bidang keahlian, penguasaan ICT, penguasaan bahasa asing, komunikasi, teamwork, independensi, pelaporan BKD secara mandiri.

3. Kompetensi Manajerial Pejabat eselon dan non-eselon; mampu merencanakan, melaksanakan dan mengevaluasi tugas sesuai tupoksi masing-masing.

4. Kompetensi Pelayanan; mampu merencanakan, melaksanakan dan mengevaluasi tugas sesuai standar pelayanan minimum masingmasing. 
5. Kompetensi Riset; kemampuan metodologi, responsif terhadap isu-isu strategis, integritas keilmuan, komunikasi dan publikasi hasil riset

6. Kompetensi

Pengabdian; kemampuan memenuhi kewajiban peng-abdian masyarakat berbasis penelitian.

7. Kualifikasi Kepribadian Muslim dan Sosial; memiliki integritas terhadap nilai-nilai Islam transformatif serta menjunjung tinggi nilai-nilai humanis.

\section{METODE PENELITIAN}

Implementasi Lesson Study ini telah dilaksanakan di

$\begin{array}{ll}\text { Fakultas } & \begin{array}{l}\text { : Fakultas Syariah dan } \\ \text { Hukum UIN Sunan }\end{array} \\ & \text { Ampel Surabaya } \\ \text { Jurusan } & : \text { Hukum Perdata } \\ \text { Program studi : } & \text { Perbandingan } \\ & \text { Mahdzab } \\ \text { Mata kuliah } & : \text { Kajian Teks Arab } \\ \text { Semester } & \text { : IV (Empat) }\end{array}$

\section{HASIL PENELITIAN}

Pelaksanaan lesson study di prodi Perbandingan Mahdzab Fakulas Syariah Dan Hukum Universitas Islam Negeri Sunan Ampel Surabaya pada tahun 2018 yang diadakan berkat penelitian tahun 2018 pada cluster pengembangan program studi ini telah memberikan kontribusi terhadap peningkatan kualitas pembelajaran dan perbaikan mutu dosen.
Hasil dari penelitian ini sejalan dan hampir sama dengan yang dituliskan oleh Subadi (2012:8) yang meliputi antara lain:

1. Peningkatan Persiapan Pembelajaran. Sebelum pelaksanaan perkuliahan semua dosen di Perbandingan Mahdzab Fakulas Syariah Dan Hukum Universitas Islam Negeri Sunan Ampel Surabaya telah diwajibkan oleh pimpinan kampus untuk membuat rencana pembelajaran semester (RPS) tetapi karena ada beberapa faktor, diantaranya kurangnya keseriusan, sehingga tugas tersebut belum terselesaikan. Dengan adanya program lesson study melalui skema penelitian tahun 2018 pada cluster pengembangan program studi yang mengambil focus penelitian dalam penerapan lesson study ini mendorong dosen sebelum mengajar untuk berusaha menyiapkan SAP dan rencana pembelajaran perkuliahan dengan perangkatnya termasuk menyiapkan LKM (Lembar Kegiatan Mahasiswa).

Dengan adanya lesson study ini, peneliti yang sekaligus dosen pengampu mata kuliah yang menjadi sasaran lesson study memiliki kewajiban untuk mengembangkan perangkat pembelajarannya dalam sesi plan. Proses inilah membuat peneliti ketika akan mengajar betul-betul 
siap, karena harus memperbaiki perangkat pembelajaran sesuai dengan kompetensi yang akan dikembangkan, membuat media yang sesuai dengan konten, menyusun lembar kerja mahasiswa sesuai dengan kegiatan dan lain-lain. Hal-hal tersebut di atas antara lain yang membedakan kesiapan dosen model sebelum dan sesudah pelaksanaan lesson study.

2. Menumbuhkan Kerja sama di dosen.

Pembinaan dosen berbasis lesson study mendorong peneliti dalam aktivitas perkuliahan dilakukan secara kerjasama dengan tim dosen, proses kolaborasi ini berdampak pada peningkatan proses pembelajaran. Proses kolaborasi antar dosen melalui pendekatan lesson study ini juga mendorong peneliti dalam perkuliahan menggunakan strategi pembelajaran yang inovatif sesuai dengan karakter materi masingmasing. Dampak dari pembelajaran tersebut, menciptakan pembelajaran aktif, inovatif, kreatif, efektif dan menyenangkan.

3. Kontribusi Pengembangan Strategi Pembelajaran.

Pendekatan pembelajaran berbasis lesson study dengan menggunakan strategi pembelajaran aktif, inovatif, kreatif, efektif dan menyenangkan ini lebih menyadarkan dosen sekaligus memberikan gambaran kepada dosen lain yang bukan dosen model dalam mengimplentasikan langkahlangkah pembelajaran. Dampak dari kegiatan ini menghasilkan indikator kriteria proses pembelajaran yang menekankan pada aspek kognitif tingkat tinggi, yaitu: a) ketajaman daya analisis dan evaluasi, b) pengembangan kreativitas dan kemandirian mahasiswa, dan c) pengembangan aspek-aspek afektif dan academic skill bagi mahasiswa. Academic skill yang diperoleh dengan pengembangan lesson study ini terdiri dari empat skill yaitu skill of academic knowledge, skill of thinking, management skill and communication skill.

4. Kontribusi Kolegialitas.

Pandangan yang mengatakan bahwa kelas adalah otoritas dosen, segala sesuatu yang terjadi di dalam kelas adalah kewenangan dosen yang bersangkutan, sehingga dosen lain tidak perlu tahu yang terjadi di dalam kelasnya, dosen lain pun seolah-olah tidak peduli dengan pembelajaran yang dilakukan oleh koleganya, pandangan seperti ini tidak selamanya dapat dibenarkan. Pandangan ini mengakibatkan perkembangan profesionalisme dosen tidak 
terpantau dengan baik. Jika ada permasalahan dengan mahasiswa, maka sulit dideteksi akar permasalahannya. Lesson Study mampu meberikan solusi dan memberikan masukan kepada dosen yang berpandangan seperti di atas, yang kemudian secara kolegialitas berdampak kepada dosen lain. Selain itu dengan adanya kegiatan lesson study selama satu semester, dosen satu rumpun bidang keahlian akan bertemu minimal delapan kali untuk mendiskusikan pembelajaran mata kuliahnya, saling memberikan koreksi, saling memberikan masukan, dan pada gilirannya akan meningkatkan kemampuan ibadah dari ke 4 madzhabemik tingkat tinggi.

5. Kesiapan Belajar Mahasiswa.

Dalam perkuliahan sering kali kontrol terhadap aktivitas pembelajaran mahasiswa kurang, akibatnya beberapa mahasiswa tidak “ tuning" dengan perkuliahan. Ini ditemukan oleh dosen obse rver saat mengamati proses pembelajaran yang dilakukan oleh dosen model. Implementasi Lesson study ini dapat meningkatkan kemampuan pedagogik dengan tercapainya indekator yang telah ditetapkan oleh universitas. Adapun indikator yang ditetapkan oleh universitas meliputi perencanaan, proses pembelajaran dan evaluasi..

Terkait dengan perencanaan, maka implementasi lesson study ini telah dapat menghasilkan silabi sebagaimana terlampir, selain itu juga tersusun rencana pembelajaran semester, dan rancangan proses pembelajaran.

Terkait dengan proses pembelajaran, implementasi lesson study dapat merekam seluruh aktifitas selama proses pembelajaran baik yang dilakukan oleh tenaga pendidik, maupun oleh peserta didik. Sedangkan terkait dengan evaluasi, maka implementasi lesson study ini dapat menghasilkan penilaian yang otentik.

\section{KESIMPULAN}

Berdasarkan uraian yang telah dikemukakan di atas, dapat diambil kesimpulan bahwa:

1. Langkah-langkah implementasi Lesson Study (LS) di Prodi Perbandingan Mahdzab Fakultas Syariah dan Hukum UIN Sunan Ampel Surabaya mengikuti kajian teori yang ada dalam LS yaitu tahap plan do see.

2. Hasil implementasi Lesson Study (LS) di Prodi Perbandingan Mahdzab Fakultas Syariah dan Hukum UIN Sunan Ampel Surabaya terhadap peningkatan kompetensi pendidik secara kulaitatif memiliki pengaruh, $\mathrm{hl}$ ini 
Didaktis: Jurnal Pendidikan dan Ilmu Pengetahuan

e-issn 2614-0578

Vol.19 No.1 Tahun 2019

p-issn 1412-5889

tercermin pada kesiapan oleh

dosen pengampu sebelum

melakukan perkuliahan. 
DAFTAR PUSTAKA

Anggara, Rian dan Umi Chotimah. 2012. Penerapan Lesson Study Berbasis Musyawarah Guru Mata Pelajaran (Mgmp) Terhadap Peningkatan Kompetensi Profesional Guru PKN SMP Se-Kabupaten Ogan. Jurnal Forum Sosial, Vol. V, No. 02,

Ibrohim, 2010. Apa, Mengapa dan Bagaimana Lesson Study: Pola Alternatif untuk Meningkatkan Efektivitas Praktik Pengalaman Lapangan (PPL) Mahasiswa Calon Pendidik. Makalah disajikan dalam Workshop Pembimbingan PPL Berbasis Lesson Study di FS UM, Tanggal 26 Januari 2010.

Padlurrahman, dan Baiq Ariani Novianti. 2013. Peningkatan Kompetensi Dosen Melalui Lesson Study Pada Program Studi Pendidikan Fisika STKIP Hamzanwadi Selong Jurnal EducatiO Vol. 8 No.

Subadi, Tjipto. 2012. Peningkatan Profesional Dosen Melalui Program Perluasan Lesson Study Pada Jurusan P Mipa Program Studi Pendidikan Matematika Dan Pendidikan Biologi Fakultas Keguruan Dan IImu Pendidikan Universitas Muhammadiyah Surakarta. Makalah disampaikan dalam seminar Nasional Pendidikan Matematika Di Surakarta, pada tanggal 09 Mei 2012

Susilo, Herawati. 2013 . Lesson Study Sebagai Sarana Meningkatkan Kompetensi Pendidik. Makalah disajikan dalam Seminar dan Lokakarya PLEASE 2013 di Sekolah Tinggi Theologi
Aletheia Jalan Argopuro 28-34 Lawang, tanggal 9 Juli 2013.

Wang-Iverson, Patsy and Yoshida, Makoto (Editors). 2005). Building Our Understanding of Lesson Study, Philadelphia, PA: Research for Better Schools

http://www.uinsby.ac.id/id/187/renc ana-strategi.html diakses tanggal 10 Agustus 2017 